\title{
Comparison of Sexual Attitudes and Attachment Styles of Patients With Bipolar I Disorder, Borderline Personality Disorder and Healthy Controls
}

\author{
Tolga ŞAKAR ${ }^{1}$, Ayhan ÇAKICI EŞ²
}

\begin{abstract}
The aim of this study is to analyze sexual attitudes and attachment styles of patients with Bipolar and Borderline pathologies. The sample includes 25 Bipolar and 25 borderline participants. 50 participants of control group were selected among nonpsychiatric patients at internal medicine service from Uşak State hospital. In the analyses of data One-Way ANOVA and Pearson Correlation were used. BPD and BD were determined as based on SCID 2 and DSM 5 in Uşak State Hospital by psychiatrist.Hendrick Brief Sexual Attitudes Scale (HSAS) were used to determine sexual attitudes. Attachment Styles were evaluated by Relationship Scales Questionnaire (RSQ). It was found stronger that there is a positive correlation between insecure attachments and individuals with BD and BPD. Findings indicated that were detected negative correlation among insecure attachments and utilitarian sexuality in individuals with BD and BPD. Future studies may be examine attack as well as euthymic periods even that should not limited as heterosexual humans.
\end{abstract}

Keywords: BD: Bipolar Disorder, BPD: Borderline Personality Disorder

\section{Bipolar I Bozukluk, Borderline Kişilik Bozukluğu ve Sağlıklı Kontrollerin Bağlanma Stilleri ve Cinsel Tutumlarının Karşılaştırılması}

Özet: $\mathrm{Bu}$ çalışmanın amacı bipolar ve borderline patolojileri olan hastaların cinsel tutumları ve bağlanma stillerini analiz etmektir. Çalışmaya bipolar grup olarak seçilen 25 katılımcı ve borderline grubu olarak seçilen 25 katılımcı dahil edildi. Uşak Devlet Hastanesi'nden iç hastalıkları servisinden psikiyatri dışı hastalar arasından 50 kontrol grubu katılımcısı seçildi. In the analyses of data One-Way ANOVA and Pearson Correlation were used. BPD ve BD Uşak Devlet Hastanesinde psikiyatrist tarafından SCID 2 ve DSM 5 esas alınarak belirlendi.Cinsel tutum, Hendrick Kısa Cinsel Tutum Ölçeği (HSAS) ile değerlendirildi.Bağlanma Stilleri, İlişki Ölçekleri Anketi (RSQ) ile değerlendirildi.Güvensiz bağlanmalarla BD ve BPD'li bireyler arasında güçlü pozitif bir ilişki olduğu bulunmuştur. Bulgular, BD ve BPD'li bireylerde güvensiz bağlanmalarla faydacı cinsellik arasında negatif korelasyon tespit edildiğini göstermiştir. Gelecekteki çalışmalar heteroseksüel insanlar olarak sınırlandırılmamalı hem de atakların yanı sıra ötimik periyotlarda incelenmeli.

Anahtar kelimeler: BD: Bipolar Bozukluk BPD: Borderline Kişilik Bozukluğu

\footnotetext{
${ }^{1}$ Exp. Psychologist., Şakar Psychological Counseling Centre, Special Öztan Hospital Uşak-Turk

${ }^{2}$ Assist. Prof., Near East University, Department of Psychological Counseling and Guidance.

Address of correspondence/ Yazışma adresi: Tolga Şakar, Şakar Psikolojik Danışma Merkezi, Özel Öztan Hastanesi, Uşak-Türkiye. Email: sakartolga387@gmail.com

Date of received/ GelişTarihi: 20.05.2019, Date of acceptance/ Kabul Tarihi: 08.07.2019

Citing/ Referans Gösterimi: Şakar, T. \& Çakıcı Eş, A., (2019). Comparison of Sexual Attitudes and Attachment Styles of Patients With Bipolar I Disorder, Borderline Personality Disorder and Healthy Controls. Cyprus Turkish Journal of Psychiatry \& Psychology, 1(2): 116-22 doi:10.35365/ctjpp.19.1.14
} 


\section{Introduction}

Bipolar Disorder (BD) and Borderline Personality Disorder (BPD) explained as a recurrent fluctuated mood periods such as impulsive sexual risky behaviors and desires (Eroğlu, 2010). Symptoms of personality disorder seen in \%48 of patients with BD (Yüksel, Kurt, Tüzer\&Göka 2004). Acording to another study, depressive and manic symptoms weren't opposite poles (Johnson, Morriss, Scott, Paykel, Kinderman Kolamunnage- Dona \& Bentall, 2011). Family history, response to treatment and progress of treatment show us that, BPD and mood disorders were associated with each other (Öztürk \& Uluşahin, 2001). BPD may overlaps with $\mathrm{BD}$ and major depressive disorder due to similarities with mood disorders (Biskin \& Paris, 2012). According to Young's schema model, patients with BPD may have abandonment beliefs due to changeable mood (Beck, 2008). Individuals with BPD may have irregular sexual anxiety related with hunger to objects due to cannot tolerate the loneliness, so they may have "impulsive sexual behavior" to avoid real or imagined abandonment (Köroğlu, 2011). According to Masterson's, if caregiver has only bad or only good attitude to child, then other humans may have completely good or fatally bad meaning for the child (Aydın, 2010). According to attachment theory of Bowlby and Ainsworth, the quality of life was determined to lifelong relationships by nature of relationships at earlier life (Çapan, 2009). If problem was occurred during attachment, protest, despair and detachment may occur (Göçener, 2010). Bowlby's concept of attachment is related with deep emotional bond due to needs for belonging and trust (Kırımer, Sümer \& Akça, 2014). The most important factors for attachment are continued proximity, secure base and safe haven (Özer, 2011). Secure attachment could disrupted by mood disorders (Kesebir, Kavzoğlu \& Üstündağ, 2011). Individuals with secure attachment have no fear of abandonment due to self-esteem (İlhan, Özdemir 2012). BPD may appropriate to darker or the less stable state than BD 2, as it continuously tides between depression or irritable hypomania and cyclothymic temperament (Çalışır, 2008). According to another research, BPD may included within Bipolar spectrum due to common neurobiological, neuroimaging and neuroscientific findings, similar emotional instability and impulsivity (Agius, Lee, Gardner\&Wotherspoon, 2012). It is known that reported that $12-23 \%$ of patients with BD2 involved BPD criterias, so "Spectrum" should be considered as a more wide range as well as similarities about mood instability, impulsivity and developmental stages (Elisei, Anastasi \& Verdolini, 2012). On the other hand, completely common etiology could not yet defined among BPD and BD (Paris, Gunderson \& Weinberg., 2007). Many BPD conditions may seen as manic depression (Stone, 1979). Ratio of self-demolition of mood disorders were determined highly over as $60 \%$ just like BPD (Uğur, Tamam, Özpoyraz \& Demirkol, 2012).

According to some researchers, both of BD and BPD may overlap as phenomenological common features, impulsivity, comorbidity, treatment responses, so BDP must be involve in axis I disorders. Acording to Paris and friends, BPD patients had ratio of BD1 as average range of $9.2 \%$ and ratio of $\mathrm{BD} 2$ as average range of $10.7 \%$. Also, comorbidity rates of cyclothymia and BPD were $62 \%$. According to Akiskal, BPD was defined as mild or soft BD (Belli, Ural \& Akbudak, 2013). According to
Otto-Salaj and Stevenson, patients with BD may live unprotected risky random sexual intercourses with extreme sexual desires during manic attack (Karadağ, Hariri \& Kenar, 2004). Uncontrolled sexual activity may good part of self-expression during mania, so this situation may cause conflicts within relationships (McCandless \& Sladen, 2003). Hypersexuality is a common symptom of mania-hypomania for children and adolescents with $\mathrm{BD}$, so the girls with $\mathrm{BD}$ had vulnerability due to hypersexuality (Basco \& Celis-de Hoyos, 2012). Individuals with BPD may have emptiness or abandonment feelings, unstable self image, emotional instability and impulsivity (Valentiner, Hiraoka \& Skowronski, 2014). Sexual rarity was reported during to depression, so sexual problems may be dependent on the changes related with BD (Lam, Donaldson, Brown \& Malliaris, 2005). Sexual dysfunction of women with BPD was determined higher than to healthy women in another study (Schulte-Herbrüggen, Ahlers, Kronsbein, Rüter, Bahri, Vater \& Roepke, 2009). It is also known that trauma was related with BPD. Espacially sexual abuse was the most effective trauma for BPD (Sansone, Chu \& Wiederman, 2001). Sexuality was a tool to prevented chronic emptiness, abandonment, anxiety, perversions, and ambivalence feelings due to insecure attachment (Bouchard, Godbout, \& Sabourin, 2009).

The aim of this study is investigating the sexual attitudes (espacially randomly and biological-utilitarian sexual attitudes) of three different groups which are BD, BPD and non-psychiatric control group according to their attachments styles.

\section{Method}

This study was conducted in Uşak, Turkey, between March and July 2015. It included 100 Turkish participants (25 with BD, 25 with BPD, 50 with nonpsychiatric). The participants' age varied between 18-50 years. Participation to the study was as voluntary and the participants were selected through random sampling method from Psychiatry Polyclinic by psychiatrist with Scid 2 and DSM4. The participation started in Uşak State hospital. Informed consent form was completed by the participants before the study. The questionnaire consist of, Socio-demographic Information Form, Relationship Scales Questionnaire (RSQ) and Hendrick Brief Sexual Attitudes Scale (HSAS). Participants completed the questionnaires approximately in 20 minutes. Ethics committee approval were available.

Hendrick Brief Sexual Attitudes Scale (HSAS): HSAS which was developed by Hendrick et al includes 23 items. The aim of this scale is to measure sexual attitudes such as indiscriminate sexuality with permissiveness subscale, responsible sexuality with birth control subscale, idealistic sexuality with communion subscale, biological-utilitarian sexuality with the instrumentality subscale. Namely, scale was used as a tool to measure different sexual attitudes. Each item is rated on a 5 point likert type scale and answers vary between "strongly agree" to "strongly disagree ". Higher scores indicate higher level of sexual attitudes and lower level of sexual attitudes. Original scale was translated and adapted to Turkish by Özgür Karaçam, Tarık Totan, Yeşim Babür Korkmaz ve Mehmet Koyuncu, also reliability and validity were good (Karaçam, Korkmaz \& Koyuncu, 2012). 
Relationship Scales Questionnaire (RSQ): RSQ was developed in 1994 by Griffin and Bartholomew. Then, it was adapted into Turkishby Sumer and Gungor in 1999. There are four sub-scales aimed at measuring the adult attachment styles, such as consisting to secure, preoccupied, dismissing and fearful attachment in RSQ. RSQ are a scale to be stylish in 7th to answer the Likerttype 30 items as total for each item 1 "no not like me" and 7 "totally like me" (Sümer \& Güngör, 1999).
Statistical Analysis: All the analyses were performed by using a computer program for the multivariate statistics; Statistics Package for the Social Sciences (SPSS), version 20 for Windows. ANOVA and Pearson Correlation were made to statistical analysis. Numerical datawas compared obtained from the objective test results.

\section{Results}

Table1.Comparisonof mean score of "permissiveness"(randomly sexual attitudes) and instrumentally" (biologicalutilitarian sexual attitudes) between BD-BPD-Control groups $(\mathrm{p}<0.05)$

\begin{tabular}{lccc}
\hline Permissivenes & & $\mathrm{Nm} \pm \mathrm{sd}$ & $\mathrm{F}(\mathrm{p})$ \\
\hline BD & 25 & $19.84 \pm 3.44$ & 89.40 \\
BPD & 25 & $21.16 \pm 5.42$ & $\left(0.000^{*}\right)$ \\
CONTROL & 50 & $33.82 \pm 5.40$ & \\
\hline Instrumentally & & & \\
\hline BD & 25 & $9.52 \pm 3.22$ & 7.552 \\
BPD & 25 & $10.28 \pm 2.46$ & $(0.001)$ \\
CONTROL & 50 & $11.78 \pm 2.12$ & \\
\hline
\end{tabular}

Participants with BD-BPD-Control were compared with permissiveness and instrumentally subscales of HSAS by One-Way ANOVA. Further analysis with Tukey shown, Control groups had significantly bigger mean scores than $\mathrm{BD}$ and BPD groups. There wasn't significantly differences between BD and BPD groups than to control group. As a result, participants with BD and BPD had different as lowest "randomly sexual attitudes" than to Control group. On the other hand, participants with BD and BPD had different "biological-utilitarian sexuality" than to participants of Control group.

Table 2. Comparison of mean score of "Attachment Styles" according to participants with BD-BPD-Control groups $(\mathrm{p}<0.05)$

\begin{tabular}{lccc}
\hline Secure Attachment & $\mathbf{N}$ & $\mathrm{m} \pm \mathrm{sd}$ & $\mathrm{F}(\mathrm{p})$ \\
BD & 25 & $24.56 \pm 5.64$ & 56.26 \\
BPD & 25 & $23.36 \pm 4.79$ & $\left(0.000^{*}\right)$ \\
CONTROL & 50 & $34.64 \pm 4.86$ & \\
Preoccupied Attachment & & & \\
BD & 25 & $26.52 \pm 6.02$ & 35.75 \\
BPD & 25 & $27.12 \pm 4.40$ & $\left(0.000^{*}\right)$ \\
CONTROL & 50 & $18.54 \pm 4.51$ & \\
Fearful Attachment & & & \\
BD & 25 & $49.00 \pm 7.33$ & $\left(0.000^{*}\right)$ \\
BPD & 25 & $47.32 \pm 7.30$ & \\
CONTROL & 50 & $21.48 \pm 7.93$ & 80.93 \\
Dismissing Attachment & & & $\left(0000^{*}\right)$ \\
BD & 25 & $41.48 \pm 5.58$ & \\
BPD & 25 & $42.48 \pm 4.35$ & \\
CONTROL & 50 & $27.32 \pm 4.42$ & \\
\hline
\end{tabular}

Participants with BD-BPD-Control groups were compared with secure and insecure attachment subscales of RSQ by One -Way ANOVA. Control group had higher mean scores to secure attachment subscales than BD and
BPD groups. Control group had less mean scores to preoccupied-fearfull-dismissing attachments subscales than BD and BPD groups. As a result, individuals with diagnose of BD and BPD had many similar mean scores related with attachment styles than to control groups.

Table3.Correlations betweenAttachment Styles (RSQ) and instrumentally (Hendrick sub-scale) in participants with BD-BPD- Control groups:

\begin{tabular}{lll}
\hline Attachment Styles & Instrumentally \\
BD Group & $\mathbf{r}$ & $(\mathbf{p})$ \\
Secure Attachment & 0.386 & 0.057 \\
Preoccupied Attachment & $-0.419^{*}$ & 0.042 \\
Fearfull Attachment & $-0.461^{*}$ & 0.020 \\
Dismissing Attachment & -0.244 & 0.239 \\
\hline
\end{tabular}




\begin{tabular}{lcc}
\hline $\begin{array}{l}\text { Table3.Correlations between Attachment Styles (RSQ) } \\
\text { Control groups: (cont.) }\end{array}$ & \\
\hline BPD Group & & \\
Secure Attachment & 0.316 & 0.123 \\
Preoccupied Attachment & $-0.469^{*}$ & 0.018 \\
Fearfull Attachment & $-0.210^{*}$ & 0.314 \\
Dismissing Attachment & $-0.488^{*}$ & 0.013 \\
Control Group & & \\
Secure Attachment & 0.178 & 0.216 \\
Preoccupied Attachment & -0.021 & 0.882 \\
Fearfull Attachment & 0.269 & 0.058 \\
Dismissing Attachment & 0.091 & 0.532 \\
\hline
\end{tabular}

In the present study was correlated between attachment styles and instrumentally examined by Pearson correlation analysis to all of participants. Biologicalutilitarian sexuality was measured by instrumentally subscale of HSAS. It was found that there were middle level negative correlations between instrumentally and preoccupied-fearful attachments to patients with $\mathrm{BD}$. It was found that there were not any significant correlations between especially; instrumentally and secure-dismissing attachments to patients with BD. It was found that there were negative correlations between instrumentally and preoccupied-dismissing-fearful attachments to patients with BPD. It was found that there were not any significant correlations between especially; instrumentally and secure attachment to patients with BPD. It was found that there were not any significant correlations between especially; instrumentally and all of attachments to participants with Control group.

\section{Discussion}

In this study, randomly sexuality examined as a sexual attitude. Random sexuality were compared between BD, BPD and non psychiatric participants. As a result of this study the random sexuality of BD and BPD was found more similar than non psychiatric participants. Because, Patients with diagnose of BD, BPD have similar mean scores of permissiveness sub-scale. Non-psychiatric participants has a little higher mean scores in instrumentally sub scale than BD and BPD. Therefore, individuals with $\mathrm{BD}$ and $\mathrm{BPD}$ have lowest-similar random intercourse than non psychiatric individuals.

According to specific researchs at literature, the most important features of patients with BPD are intensity of the affectives and fluxional behaviors. There are quick transition another attitude from an attitude (Köroğlu, 2011).

Maybe, therefore, patients with BPD may have unstable sexual attitudes. Because, according to research of Martin Lioyd, the diagnosed with Compulsive Sexual Behavior was revised to assess symptoms of BPD in charts of 85 patients. Also, the unsafe sex practices were detected as (42.4\%)". The unsafe sex practices were one of the most commonly symptoms of patients with BPD (Lloyd, Raymond, Miner \& Coleman, 2007).

Sexuality often used as a tool as to prevent chronic feelings of emptiness and abandonment to appease of anxiety in this group of women with BPD (Bouchard, Godbout \& Sabourin, 2009).

On the other hand, according to McCandles and Sladen, sexual activity can be a pleasurable and very important part of self-expression during to manic episode of BD.
However, normally, bipolar patients may have lowest sexuality during to euthymic period than the manic phase. This research was conducted to patients within that euthymic phase, so sexuality of Bipolar and Borderline patients may be lowest. Also, Bipolar individual's living sexual indiscretions as randomly and uncontrolled during Manic episode, so then may cause conflicts in his relationships (McCandles \& Sladen, 2003).

In this study, sexual attitudes of participants of nonpsychiatric participants were higher level than to Bipolar and Borderline people but extreme sexual attitudes does not mean to be higher level of sexuality. Therefore, findings may be quite surprisingly and misleading. Whereas, sexuality may be a stigma or taboo as a thype of problems for Bipolar and Borderline patients. Bipolar and Borderline patients might wants to hide own sexual attitudes despite extreme sexual actions.Namely, sexual attitudes and sexual actions may be different from each other. Therefore, extreme sexual attitudes does not mean to be higher level of sexual actions. Because, they might wants to hide own sexual attitudes despite extreme sexual actions.

Because, according to studies of Sebastien Bouchard;there were compared as a broad spectrum to sexual attitudes and behaviors of women with BPD with, women without BPD in a research conducted at Qubec province in Canada's eastern. In this study, it was investigated relationship between sexual attitudes and their sexual activity of women with BPD. When it was compared, women with BPD have more sexual partners than females in control group. Women in the control group have, more exceeded than $6 \%(n=2)$ sexual partner to along lifetimes, women with BPD have more exceeded than sexual partners to $50 \%(\mathrm{n}=19)$ along lifetimes for sexual activity. In BPD group were higher to prejudice to sexuality. However, women with BPD had more sexual partners Also, according to studies of Sebastien Bouchard, women with BPD overmuch feels pressure to sexual intercourse. Therefore, women with BPD have more sexual partners than women without BPD, so they feels to more pressure for sex in themselves (Bouchard, Godbout \& Sabouring, 2009).

According to another studies of Karadağ, patients with BD live erotomania and impulse control difficulties during manic attack, they may enter into the indiscriminate sexual intercourse as biological and utilitarian and also they have inability to resist forced unwanted sexual relationship (Karadağ, Hariri \& Kenar, 2004).

As a result, in this study, random, biological and utilitarian sexual attitudes of individuals with BD and BPD have lovest level as similar as non psychiatric individuals. Individuals with $\mathrm{BD}$ and $\mathrm{BPD}$ may have extreme sexual actions. Also, patients with BD and BPD 
selected for this study in euthymic period. Sexual attitude was minimized in euthymic period due to some causes like this drug use. Therefore, it is not a amazing dilemma.

In this study, patients with BD and BPD have most insecure attachment than non psychiatric participants. According to another study, the majority of Borderline individuals have an insecure attachment style as evident with distrust of others and fear of abandonment. According to spesific studies at literature, healthy participants of control group have higher secure attachment, lower anxious, and lower preoccupied attachment scores than to patients with BD (Morriss, van der Gucht, Lancaster \& Bentail, 2009).

On the other hand, patients with BPD are characterized by irregular attachment styles. Already, abandonment depression of Borderline patients were related with expression of insufficiency of object (Masterson, 2008).

According to this study, patients with BD and BPD had lowest secure attachment as different as non psychiatric participants. There were found statistically significant differences between especially; non psychiatric and Bipolar group, non psychiatric and Borderline group. As a result, individuals with $\mathrm{BD}$ and BPD have less secure attachment, so non psychiatric individuals have more secure attachment. Patients with BD and BPD had biggest preoccupied attachment different than non psychiatric participants. There were found statistically significant differences between especially; non psychiatric and Bipolar group, non psychiatric and Borderline group. As a result, patients with $\mathrm{BD}$ and $\mathrm{BPD}$ have bigger fearful attachment, so non psychiatric participants have less fearful attachment. Patients with $\mathrm{BD}$ and BPD had more fearful attachment than non psychiatric participants. There were found statistically significant differences between especially; non psychiatric and Bipolar group, non psychiatric participants and Borderline group. As a result, Patients with BD and BPD have bigger fearful attachment, so non psychiatric participants have less fearful attachment. Patients with BD and BPD had biggest dismissing attachment different than non psychiatric participants. There were found statistically significant differences between especially non psychiatric and Bipolar group, non psychiatric and Borderline group. As a result, Patients with BD and BPD have more dismissing attachment, so non psychiatric participants have less dismissing attachment. In this study, it was found middle level negative correlations between instrumentally and preoccupied attahment in Bipolar patients. Therefore, Bipolar individuals with preoccupied attached may have lowest biological-utilitarian sexuality. Because, this result show us biological-utilitarian sexuality increased during to preoccupied attahment decreased, so biologicalutilitarian sexuality decreased during to preoccupied attahment increased in Bipolar patients. It was found that there were middle level negative correlations between instrumentally and fearful attachment in Bipolar patients. Therefore, Bipolar individuals with fearful attached may have lowest biological-utilitarian sexuality. Because, this result show us biological-utilitarian sexuality increased during to fearful attachment decreased, or it occurs just the opposite in Bipolar patients. As a result, Bipolar individuals with preoccupied attached may have not more biological-utilitarian sexuality due to lowest manic symptoms in euthymic episode. Whereas, according to
McCandles and Sladen in another study, sexual activity can be a pleasurable and very important part of self expression during to manic episode of BD (McCandles \& Sladen. 2003).

In this study, it was found middle level negative correlations between instrumentally and preoccupied attahment in Borderline patients. Thus, Borderline individuals with preoccupied attached may have lowest biological-utilitarian sexuality as a sexual attitude. Because, this result show us biological-utilitarian sexuality decreased during to preoccupied attahment increased, or it occurs just the opposite in Borderline patients. It was found that there were middle level negative correlations between instrumentally and fearful attahment in Borderline patients. Namely, Borderline individuals with fearful attached may have lowest biological-utilitarian sexuality as a sexual attitude. Because, this result show us biological-utilitarian sexuality decreased during to fearful attahment increased, or it occurs just the opposite in Borderline patients. Also, biological-utilitarian sexuality increased during to dismissing attahment decreased in Borderline patients. This situation was detected as a unique differ in Borderline patients than to Bipolar group as well as Control group.According to another specific study, women with BPD is considered to had dysfunctional attitudes against sexuality, so it was detected Borderline women had more anxious attachment than to other women by regression analysis. Women with BPD may feel compelled to have sex with their partners due to anxious attachment and to appease the fear of rejection (Bouchard, Godbout \& Sabourin, 2009).

Another study related with romantic attachment styles of men with sex addicted. ANOVA revealed that sexually addicted men are more likely to relate with insecure attachment styles (Zapf, Greiner \& Carroll, 2008).

As a result, in this study, random, biological-utilitarian sexual attitudes and attachment styles of individuals with BD and BPD were detected most similar than non psychiatric individuals. In generally, there were detected more correlation among sexual attitudes and attachment styles in individuals with healty than individuals with BD and BPD. Also, there were detected more correlation among biological-utilitarian sexual attitudes and attachment styles in individuals with BD and BPD. Therefore, similarities among sexuality and attachment styles of individuals with $\mathrm{BD}$ and $\mathrm{BPD}$ than non psychiatric individuals may be referred in this study.

Acording to another study at literature, sexuality is affects to quality of life. On the other hand, discontented human not want sexual act without exciting with foreplay/touches of satisfactory. According to another study, men who answered rated experiencing pleasure as the most important factors related with fulfil partner's needs, achieve orgasm, maintain a good erection, having foreplay. Women rated having foreplay as the main factor, together with a romantic relation and to experience pleasure, fulfil partner's needs, experience sexual desire, achieve orgasm, satisfaction after sex, experience intercourse of desired length, and to maintain a good lubrication (Waldkirch \& Buvat, 2007). BPD and BD patients have same sexual satisfactions (Şakar \& Çakıcı Eş, 2019). 


\section{Conclusion}

As a result, according to this study, both of pathologies with BPD and BD are similar pathologies to sexual attitudes and attachment styles. Because, sexuality quite to hidden and unique as a stigma for a lot of people. There was found hidden attachment styles behind of the sexuality in humans with Bipolar and Borderline pathologies. There were detected their sexualities as similar manner affected of attachment styles of both of patients with Bipolar Disorder and patients with Borderline Disorder. Results were found just like expected due to patients with BD and BPD in euthymic period. Patients with BD and BPD have similar randomly, biological-utilitarian sexual attitudes than to healthy controls in this case. In individuals with bipolar and borderline pathologies were found completely similar attachment styles than non psychiatric healthy individuals. On the other hand, there were found correlation between attachment styles and biologicalutilitarian sexuality of patients with BD and BPD than non psychiatric healthy individuals. Results might not be completely enough and specific because only heterosexuel participants in euthymic episode was included at this study. However examination in euthymic episode was seen appropriate for patients with BD and $\mathrm{BPD}$, because sexuality is a sensitive topic. However, in the future studies patients with BD and BPD may examine attack as well as euthymic periods. Participants should not limited with heterosexuel participants in the future studies. Thus sexual attitudes of participants could examined better. Another studies and this studies about sexuality and attachment styles in individuals with BD and BPD must be evaluate as parts of an entire just like a puzzle for the future studies.

\section{References}

Agius, M., Lee, J., Gardner, J., \& Wotherspoon, D. (2012). Bipolar II disorder and borderline personality disorder-comorbidity or spectrum. Psychiatr Danub, 24(suppl 1), S197-201.

Aydın, M. (2010). Masterson Yaklaşımında Borderline Kişilik Bozukluğunda Gelişimsel Yaklaşım. (Unpublished Master Thesis) Istanbul: İstanbul Ticaret Üniversitesi.

Basco, M. R., \& Celis-de Hoyos, C. E. (2012). Biopsychosocial model of hypersexuality in adolescent girls with bipolar disorder: strategies for intervention. Journal of child and adolescent psychiatric nursing, 25(1), 42-50.

Beck, A.T. (2008). Kişilik Bozuklukları Bilişsel Terapisi. (Çev. Yalçın, Ö. ve Akçay, N.E.). İstanbul: Litera Yayıncılık.

Belli, H., Ural, C., \& Akbudak, M. (2013). " Borderline" Kisilik Bozuklugu: Duygudurum Dengeleyicilerinin Tedavideki Yeri/Borderline personality disorder: the place of mood stabilizers in the treatment. Dusunen Adam, 26(1), 72.

Biskin, R. S., \& Paris, J. (2012). Diagnosing borderline personality disorder. CMAJ, 184(16), 1789-1794.

Bouchard, S., Godbout, N., \& Sabourin, S. (2009). Sexual attitudes and activities in women with borderline personality disorder involved in romantic relationships. Journal of Sex \& Marital Therapy, 35(2), 106-121.

Corona, G., Petrone, L., Mannucci, E., Magini, A., Lotti, F., Ricca, V., ... \& Maggi, M. (2006). Assessment of the relational factor in male patients consulting for sexual dysfunction: the concept of couple sexual dysfunction. Journal of andrology, 27(6), 795-801.

Çalışır, M. (2008). Sınırda Kişilik Bozukluğu Aslında Bir Bipolar Spektrum Bozukluğu mudur?. Klinik Psikiyatri Dergisi, $11(3)$.

Çapan, B. E. (2009). Öğretmen adaylarinin kişilerarasi ilişkileri ve bağlanma stilleri arasindaki ilişki. Anadolu University Journal of Social Sciences, 9(2).

Elisei, S., Anastasi, S., \& Verdolini, N. (2012). The continuum between bipolar disorder and borderline personality disorder. Psychiatr Danub, 24(suppl 1), S143-S146.

Eroğlu, Z.M-. "Bipolar Bozuklukta Koruyucu Sağaltım". (Unpublished Master Thesis) Çukurova Üniversitesi Tip Fakültesi Psikiyatri Anabilim Dalı, 2(2):206-236 2010.

Göçener, D. (2010). Üniversite öğrencilerinin güvenli bağlanma düzeyleri ile kișilerarası ilişki tarzları arasındaki ilișkiler. (Unpublished Master Thesis). Ankara: Ankara Üniversitesi Sosyal Bilimler Enstitüsü.

İlhan, T. \& Özdemir, Y. (2012). Beliren Yetişkinlerde Yaș, Cinsiyet ve Bağlanma Stillerinin Kimlik Statüleri Üzerindeki
Yordayıc1 Rolü. Dicle Üniversitesi Ziya Gökalp Eğitim Fakültesi Dergisi. (19) 227-241.

Karaçam, Ö. Totan, T. Korkmaz, B.Y. Koyuncu, M. (2012). Hendrick Cinsel Tutum Ölçeği Kısa Formunun Türkçeye uyarlanması, geçerlilik ve güvenilirlik çalışması. Anadolu Psikiyatri Dergisi. 13.138-144.

Karadağ, F., Hariri, A. G., \& Kenar, J. (2004). Şizofreni ve İki Uçlu Duygudurum Bozukluğu Olan Hastalarda Cinsel Yolla Bulaşan Hastalıklara Karşı Farkındalık ve Riskli Cinsel Davranışlar. Klinik Psikiyatri Dergisi, 7(1), 17-25.

Kesebir, S., Kavzoğlu, S. Ö., \& Üstündağ, M. F. (2011). Bağlanma ve psikopatoloji. Psikiyatride Guncel YaklasimlarCurrent Approaches in Psychiatry, 3(2), 321-342.

Kırımer, F., Sümer, N., \& Akça, E. (2014). Orta çocuklukta anneye kaygılı ve kaçınan bağlanma: Yakın İlişkilerde Yaşantılar Envanteri-II Orta Çocukluk Dönemi Ölçeğinin Türkçeye uyarlanması. Türk Psikoloji Yazıları, 17(33), 45-57.

Köroğlu, E. (2011). Kişilik Bozuklukları. Ankara: Hekimler Yayın Birliği.

Lam, D., Donaldson, C., Brown, Y., \& Malliaris, Y. (2005). Burden and marital and sexual satisfaction in the partners of bipolar patients. Bipolar disorders, 7(5), 431-440.

Lloyd, M., Raymond, N. C., Miner, M. H., \& Coleman, E. (2007). Borderline personality traits in individuals with compulsive sexual behavior. Sexual Addiction \& Compulsivity, 14(3), 187-206.

Masterson. F.J. (2008). Kişilik Bozuklukları. (Çev. Taylan Bozkurt, B. \& Soylu, T.V.) Istanbul: Litera Yayıncilık.

McCandless, F., \& Sladen, C. (2003). Sexual health and women with bipolar disorder. Journal of Advanced Nursing, 44(1), 4248.

Morriss, R. K., van der Gucht, E., Lancaster, G., \& Bentall, R. P. (2009). Adult attachment in bipolar 1 disorder. Psychology and Psychotherapy: theory, research and practice, 82(3), 267-277.

Özer, M. (2011). Suçluluk-utanç, bağlanma, algılanan ebeveynlik (anne) tarzı ve psikolojik belirtiler arasındaki ilişkiler. (Unpublished master thesis), Savunma Bilimleri Enstitüsü, Kara Harp Okulu, Ankara.

Öztürk, M. O. \& Uluşahin, A. (2011). Ruh Sağllğg Ve Bozuklukları 1. Ankara: Nobel Tip.

Paris, J., Gunderson, J., \& Weinberg, I. (2007). The interface between borderline personality disorder and bipolar spectrum disorders. Comprehensive psychiatry, 48(2), 145-154. 
Sansone, R. A., Chu, J. W., \& Wiederman, M. W. (2011). Sexual behaviour and borderline personality disorder among female psychiatric inpatients. International journal of psychiatry in clinical practice, 15(1), 69-73.

Schulte-Herbrüggen, O., Ahlers, C. J., Kronsbein, J. M., Rüter, A., Bahri, S., Vater, A., \& Roepke, S. (2009). Impaired sexual function in patients with borderline personality disorder is determined by history of sexual abuse. The journal of sexual medicine, 6(12), 3356-3363.

Stone, M. H. (1979). Assessing vulnerability to schizophrenia or manic-depression in borderline states. Schizophrenia bulletin, 5(1), 105-110.

Sümer, N., \& Güngör, D. (1999). Yetişkin bağlanma stilleri ölçeklerinin Türk örneklemi üzerinde psikometrik değerlendirmesi ve kültürlerarası bir karşılaşıırma. Türk Psikoloji Dergisi, 14(43), 71-106.
Şakar, T., Çakıcı Eş, A., (2019). Comparison of Sexual Satisfactions and Attachment Styles of Patients with Bipolar I Disorder, Borderline Personality Disorder and Healthy Controls. Cyprus Turkish Journal of Psychiatry \& Psychology, 1(1): $42-49$ doi:10.35365/ctjpp.19.1.05.

Uğur, K., Tamam, L., Özpoyraz, N., \& Demirkol, M. E. (2012). Bipolar bozuklukta özkıyım davranışlarının değerlendirilmesi. Cukurova Medical Journal, 44(2), 1-1.

Valentiner, D. P., Hiraoka, R., \& Skowronski, J. J. (2014). Borderline personality disorder features, self-verification, and committed relationships. Journal of Social and Clinical Psychology, 33(5), 463-480.

Yüksel, F.V., Kurt, A., Tüzer, V., Göka. E. (2004). Unipolar Mani. Klinik Psikiyatri. 7:161-166.

Zapf, J. L., Greiner, J., \& Carroll, J. (2008). Attachment styles and male sex addiction. Sexual Addiction \& Compulsivity, 15(2), $158-175$. 